\title{
Is Environmentally-Friendly Agriculture Less Profitable for Farmers? Evidence on Integrated Pest Management in Bangladesh
}

\author{
Susmita Dasgupta* \\ Craig Meisner \\ David Wheeler
}

\section{Development Research Group \\ World Bank}

\begin{abstract}
World Bank Policy Research Working Paper 3417, September 2004
The Policy Research Working Paper Series disseminates the findings of work in progress to encourage the exchange of ideas about development issues. An objective of the series is to get the findings out quickly, even if the presentations are less than fully polished. The papers carry the names of the authors and should be cited accordingly. The findings, interpretations, and conclusions expressed in this paper are entirely those of the authors. They do not necessarily represent the view of the World Bank, its Executive Directors, or the countries they represent. Policy Research Working Papers are available online at http://econ.worldbank.org.
\end{abstract}

Authors' names in alphabetical order. The authors are, respectively, Senior Economist, Consultant and Lead Economist in the World Bank's Development Research Group. Financial support for this study has been provided by the World Bank's Development Research Administration. Our special thanks to Mainul Huq, from the Development Policy Group, for organizing and conducting the survey. We are also grateful to Gershon Feder for useful comments and suggestions. 


\begin{abstract}
Concerns about the sustainability of conventional agriculture have prompted widespread introduction of integrated pest management (IPM), an ecologically-based approach to control of harmful insects and weeds. IPM is intended to reduce ecological and health damage from chemical pesticides by using natural parasites and predators to control pest populations. Since chemical pesticides are expensive for poor farmers, IPM offers the prospect of lower production costs and higher profitability. However, adoption of IPM may reduce profitability if it also lowers overall productivity, or induces more intensive use of other production factors. On the other hand, IPM may actually promote more productive farming by encouraging more skillful use of available resources. Data scarcity has hindered a full accounting of IPM's impact on profitability, health and local ecosystems.

Using new survey data, this paper attempts such an accounting for rice farmers in Bangladesh. We compare outcomes for farming with IPM and conventional techniques, using input-use accounting, conventional production functions and frontier production estimation. All of our results suggest that the productivity of IPM rice farming is not significantly different from the productivity of conventional farming. Since IPM reduces pesticide costs with no countervailing loss in production, it appears to be more profitable than conventional rice farming. Our interview results also suggest substantial health and ecological benefits. However, externality problems make it difficult for farmers to adopt IPM individually. Without collective adoption, neighbors' continued reliance on chemicals to kill pests will also kill helpful parasites and predators, as well as exposing IPM farmers and local ecosystems to chemical spillovers from adjoining fields. Successful IPM adoption may therefore depend on institutional support for collective action.
\end{abstract}




\section{Introduction}

Approximately $84 \%$ of Bangladesh's people are directly or indirectly dependent on agriculture for their livelihood, and agriculture contributes about $24 \%$ of gross domestic product (Bangladesh Bureau of Statistics, 2001). Rice is the major staple crop, accounting for $76 \%$ of the cultivated area, $78 \%$ of the irrigated area, $52 \%$ of agricultural GDP, and 71\% of caloric intake (Bangladesh Bureau of Statistics, 2001). Plant, animal and insect pests pose a constant threat to rice production, inflicting losses conservatively estimated at $10-15 \%$ annually (FAO, 2001). Farmers have used toxic chemicals extensively for pest control, because of their reputation for speed and effectiveness. However, rising use of chemical pesticides has also posed serious health risks, as well as threatening widespread ecological damage. These problems will undoubtedly increase if Bangladeshi farmers respond to rapidly-rising food demand by intensifying their use of chemicals for pest control.

In response to rising concern about the sustainability of conventional agriculture, the government has collaborated with international assistance agencies to promote Integrated Pest Management (IPM). IPM has no standard definition, but comprises approaches that range from carefully-targeted used of chemical pesticides to biological techniques that use natural parasites and predators to control pests (Sorby et al., 2003). Since chemical pesticides are expensive for poor farmers, IPM also offers the prospect of lower production costs and higher profitability. Of course, adoption of IPM may reduce overall profitability if it also lowers productivity, or induces more intensive use of other production factors. However, application of IPM techniques may also raise overall productivity, by encouraging more effective use of other inputs. Data scarcity has hindered a full accounting of IPM's impact on profitability, health and local ecosystems.

Using new survey data, this paper attempts such an accounting for farmers in Bangladesh. We compare outcomes for farming with IPM and conventional techniques, using simple input-use accounting and estimation of conventional and frontier production functions, along with farmers' assessments of their own health status and local ecological conditions.

The remainder of the paper is organized as follows. Section 2 describes recent trends in pesticide use, the associated problems, and the current status of IPM programs 
in Bangladesh. In Section 3, we introduce our survey and provide a summary description of the farmers who are currently using IPM techniques. Section 4 examines the determinants of IPM adoption, while Section 5 presents our productivity comparisons for IPM and conventional rice farming. In Sections 6 and 7, we summarize our survey results on farmers' health status and local ecological conditions. Section 8 concludes the paper and discusses some implications of our results.

\section{Agriculture and Environment in Bangladesh}

\subsection{Pesticide Use}

Like many developing countries, Bangladesh has promoted the use of pesticides to expand agricultural land and increase output per acre. Promotional activities have included extension services and significant subsidies (Rasul and Thapa, 2003; Hossain 1988). Figure 1 shows that pesticide use has more than doubled since 1992, rising from 7,350 metric tons to 16,200 metric tons in 2001. An FAO analysis of pesticide composition in Bangladesh has revealed high shares of toxic chemicals that epidemiological studies have found to cause cancer, genetic damage, fetal damage, and

\section{Figure 1: Trends in Pesticide Use, 1992-2001}

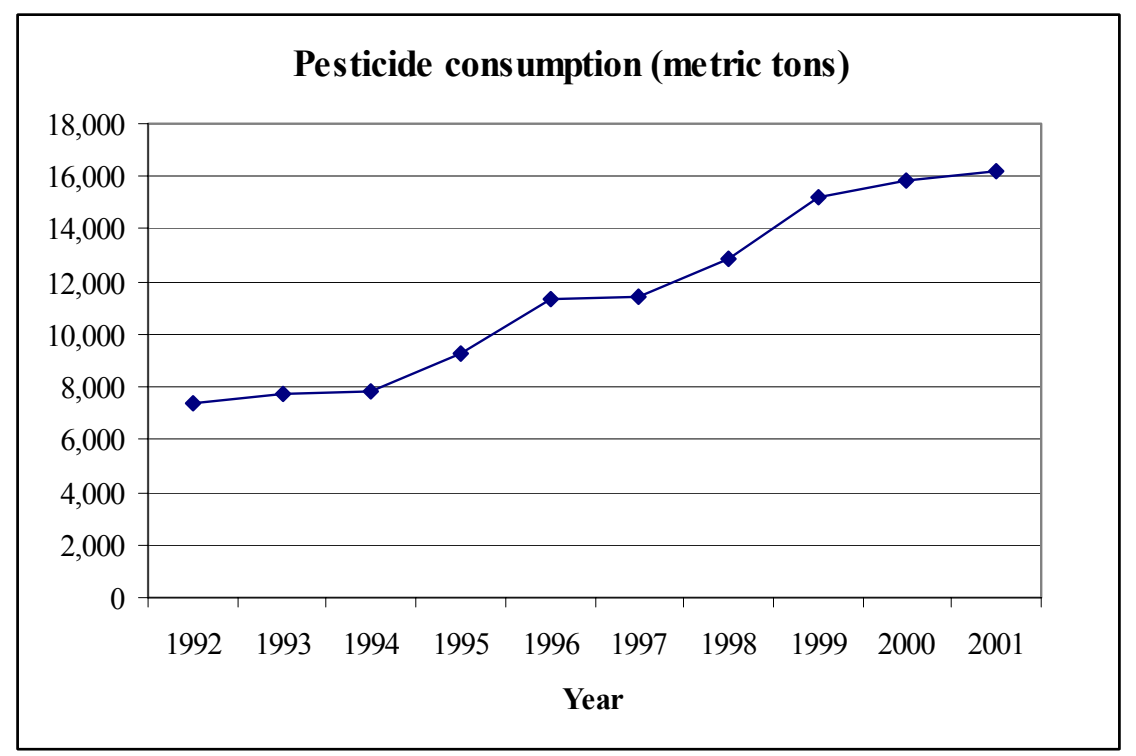

Source: Department of Agricultural Extension, Plant Protection Wing, Bangladesh 
severe allergic responses in exposed populations (Zahm, Ward and Blair, 1997). ${ }^{1}$

Many pesticides used in Bangladesh are banned or restricted under international agreements (NOVIB, 1993; SUNS, 1998; SOS-arsenic.net, 2004). In addition, several studies have shown that inadequate product labeling and farmers' lack of information have led to widespread overuse or misuse of dangerous pesticides. Substantial anecdotal evidence suggests that pesticide poisonings and ecological damage have become common in Bangladesh (Ramaswamy, 1992)

\subsection{IPM in Bangladesh}

Bangladesh's IPM activities began with rice in 1981, and the FAO played a strong catalytic role with government officials and the donor community. The program provided capacity-building for the Department of Agricultural Extension (DAE), introduced Farmer Field Schools, and trained representatives of local NGO's. Subsequently, the government and NGO's initiated several IPM projects for rice and vegetables with donor funds. ${ }^{2}$ At present, the Plant Protection Wing of the DAE is responsible for the implementation of IPM activities (FAO, 2001).

\section{Survey Data}

The research reported in this paper is based on a large survey of Bangladeshi farmers, carried out by the World Bank in the summer of 2003. We used structured questionnaires to collect information on conventional and IPM farming techniques, pesticide use and practices, applicator precautions and damage-averting behavior, health effects and environmental impacts. ${ }^{3}$ To provide greater depth, we also interviewed 139 randomly-selected rice farmers who currently use IPM.

${ }^{1}$ See Appendix I for details. The FAO study has found particularly high shares for carbamates and organophosphates, which pose the health hazards noted above.

2 To date, major IPM programs in Bangladesh have included the DAE-UNDP/FAO IPM Project (BGD/95/003); DAE-DANIDA Strengthening Plant Protection Services (SPPS) Project; Command Area Development Project (CAD); CARE-New Options for Pest Management; CARE-Integrated Rice and Fish Project (INTERFISH); AID-Comilla's Integrated Pest Management Project; USAID-funded IPM Collaborative Research Support Program; and FAO's Regional Cotton Project

${ }^{3}$ The survey was designed and supervised by the World Bank team, and conducted by the Development Policy Group in Bangladesh. To minimize reporting bias, the survey was conducted under the agreement that the team would not reveal the identity of the farms surveyed or the respondents who participated. 
We surveyed the IPM farmers in districts with significant IPM participation: Rajshahi and Rangpur in the Rajshahi division (Northwest), Comilla in Chittagong division (East), Jessore in Khulna division (West), and Kishoreganj in Dhaka division (North -- see Figure 2). We also surveyed 689 farmers who use chemical pest controls. Table 1 displays the regional distribution of farmers in our sample.

\section{Table 1: Regional Distribution of Survey Respondents}

\begin{tabular}{|l|r|r|}
\hline District & $\begin{array}{c}\text { Conventional } \\
\text { Farmers }\end{array}$ & $\begin{array}{c}\text { IPM } \\
\text { Farmers }\end{array}$ \\
\hline Bogra & 27 & 0 \\
\hline Chapainawabganj & 3 & 0 \\
\hline Chittagong & 56 & 0 \\
\hline Comilla & 61 & 31 \\
\hline Jessore & 111 & 54 \\
\hline Kishoreganj & 35 & 20 \\
\hline Munshiganj & 25 & 0 \\
\hline Narsingdi & 82 & 0 \\
\hline Rajshahi & 137 & 8 \\
\hline Rangpur & 68 & 26 \\
\hline Mymensingh & 84 & 0 \\
\hline Total & 689 & 139 \\
\hline
\end{tabular}

Among the surveyed IPM farmers, reported techniques include manual removal of pests (70\% of the sample), use of natural parasites and predators $(58 \%)$, light traps (14\%), crop rotation (10\%) and smoke (5\%). All of the surveyed IPM farmers received formal training, with more than 90\% identifying Agriculture Ministry officials as the providers. The farmers attributed their adoption of IPM to Ministry officials' recommendations (41\%); cost-saving from reduced pesticide use (33\%); environmental benefits (12\%); and improved health (6\%). About 52\% reported increased output, and reported pesticide use fell by $67 \%$.

\section{Adoption of IPM}

IPM programs have existed in our survey areas for twenty years, so it is reasonable to assume that most farmers have at least some information about them. Farmers' adoption of IPM may depend on a variety of factors, including personal characteristics 


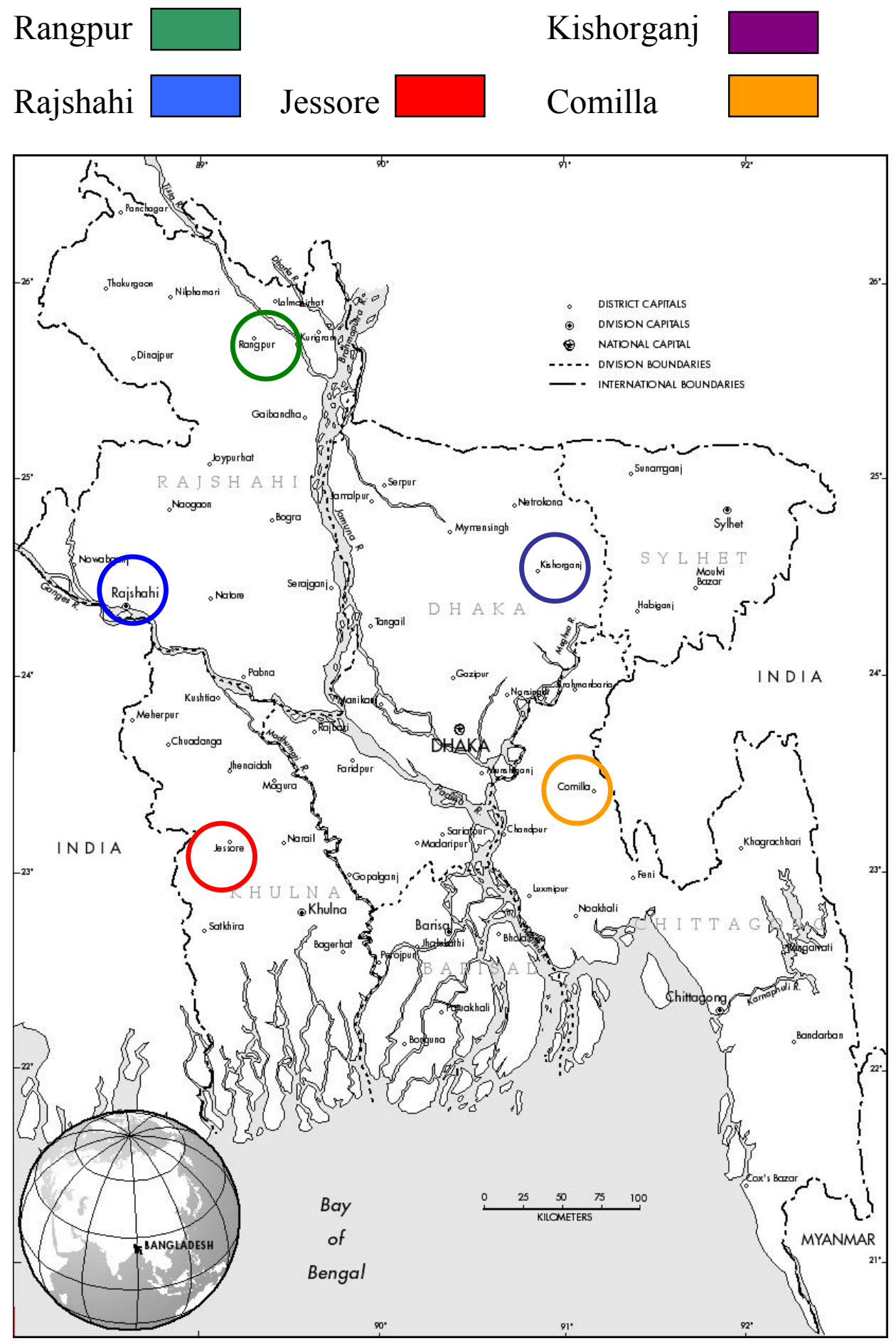

Figure 2: IPM Survey Districts in Bangladesh. 
such as education and experience, farm characteristics such as production scale, and selective judgments by Agriculture Ministry official charged with promoting such programs. Some personal and farm characteristics that influence IPM adoption could also affect productivity, so it may be important to introduce controls for these variables in a comparison of IPM and conventional farming.

Using linear probability and probit models, we test for the effects of age, education, farming experience, ownership status, prior training in pesticide use, production scale and health status on IPM use. ${ }^{4}$ Our prior expectation is that education, farm ownership, prior training and poor health are positively related to IPM adoption, while age and farming experience may be negatively related. More educated farmers may be more receptive to new techniques; owners and unhealthy farmers may perceive greater long-run gains from adoption; prior training in pesticide handling may encourage IPM adoption, by sensitizing farmers to the hazards of pesticide use; older farmers and those with long experience in conventional farming may resist new approaches. We are agnostic about production scale.

Our estimation results (Table 2) confirm some of our prior expectations but contradict others. Education, ownership, prior training, experience and poor health all have the expected signs, and the first three variables are highly significant by the conventional criteria. ${ }^{5}$ However, age has an unexpected, positive effect on adoption probability. Production scale is insignificant, suggesting (ceteris paribus) that farmers do not perceive greater scale economies in IPM than in conventional rice production. We conclude that personal and farm characteristics are significant determinants of IPM adoption, and we control for these characteristics in our production function estimation because they may affect farming efficiency as well.

\footnotetext{
${ }^{4}$ We recognize the risk of simultaneity bias for health status, so we have estimated the probability models with and without this variable. Farmers with lower health status may be more likely to adopt IPM, since it reduces exposure to dangerous pesticides. However, farmers using IPM may already have realized significant health improvement. In an IPM adoption equation that does not account for simultaneity, the measured health status effect could therefore be negative, zero or positive. We cannot account for simultaneity here, because all available instruments such as age and education are also variables in the IPM adoption equation. In any case, results for other variables are not affected by the inclusion or exclusion of health status.

5 Rejection of the null hypothesis ("no effect") with $95 \%$ confidence or greater.
} 
Table 2: Determinants of IPM Adoption in Rice Production

$\begin{array}{lll} & \begin{array}{l}\text { Linear } \\ \text { Probability }\end{array} & \text { Probit } \\ \text { Age } & 0.008 & 0.029 \\ & (3.41)^{* *} & (3.34)^{* *} \\ \text { Education } & 0.089 & 0.296 \\ & (5.37)^{* *} & (5.11)^{* *} \\ \text { Ownership } & 0.129 & 0.570 \\ & (2.42)^{*} & (2.55)^{*} \\ \text { Training } & 0.375 & 1.057 \\ & (4.27)^{* *} & (3.69)^{* *} \\ \text { Experience } & -0.003 & -0.012 \\ \text { Farm Scale } & (1.27) & (1.36) \\ & 0.001 & 0.003 \\ \text { Poor Health } & (0.11) & (0.13) \\ & -0.063 & -0.205 \\ \text { Constant } & (1.70) & (1.53) \\ & -0.232 & -2.504 \\ \text { Observations } & (2.62)^{* *} & (7.19)^{* *} \\ \text { R-squared } & 551 & 551 \\ & 0.13 & \\ & & \end{array}$

Absolute value of $t$ statistics in parentheses ${ }^{*}$ significant at $5 \% ;{ }^{* *}$ significant at $1 \%$

\section{Comparative Input Use, Productivity and Profits}

We use two quantitative techniques for assessing IPM and conventional techniques in rice production: Comparative estimates of input-output relationships, and production function estimation. In both cases, we control for farmers' characteristics (age, education, farming experience, ownership status, prior training, production scale, health status) that may affect both productivity and the propensity to adopt IPM.

\subsection{Input-Output Results}

For each farm in the sample, we calculate input-output (IO) coefficients for land, family labor, hired labor, capital, irrigation, seed, fertilizer and pesticide. We test for significant differences between mean coefficients for conventional and IPM farming by regressing the IO coefficients on a dummy variable for IPM use. Since all distributions of IO coefficients are highly skewed, we guard against outlier effects by estimating log 
regressions as well as linear regressions. ${ }^{6}$ The results, reported in Table 3, are similar for both specifications. Family and hired labor inputs per unit of output are generally lower for IPM production, suggesting that time savings from reduced pesticide applications more than compensate for reallocation of some labor to IPM-related activities. Seed inputs are also significantly lower per unit of output. As expected, pesticide inputs per unit of output are significantly lower for IPM production in both the linear and log models. However, IO coefficients for land, capital, irrigation and fertilizer are not significantly different in the two modes of production.

\section{Table 3: Impact of IPM on Input-Output Ratios for Rice Production}

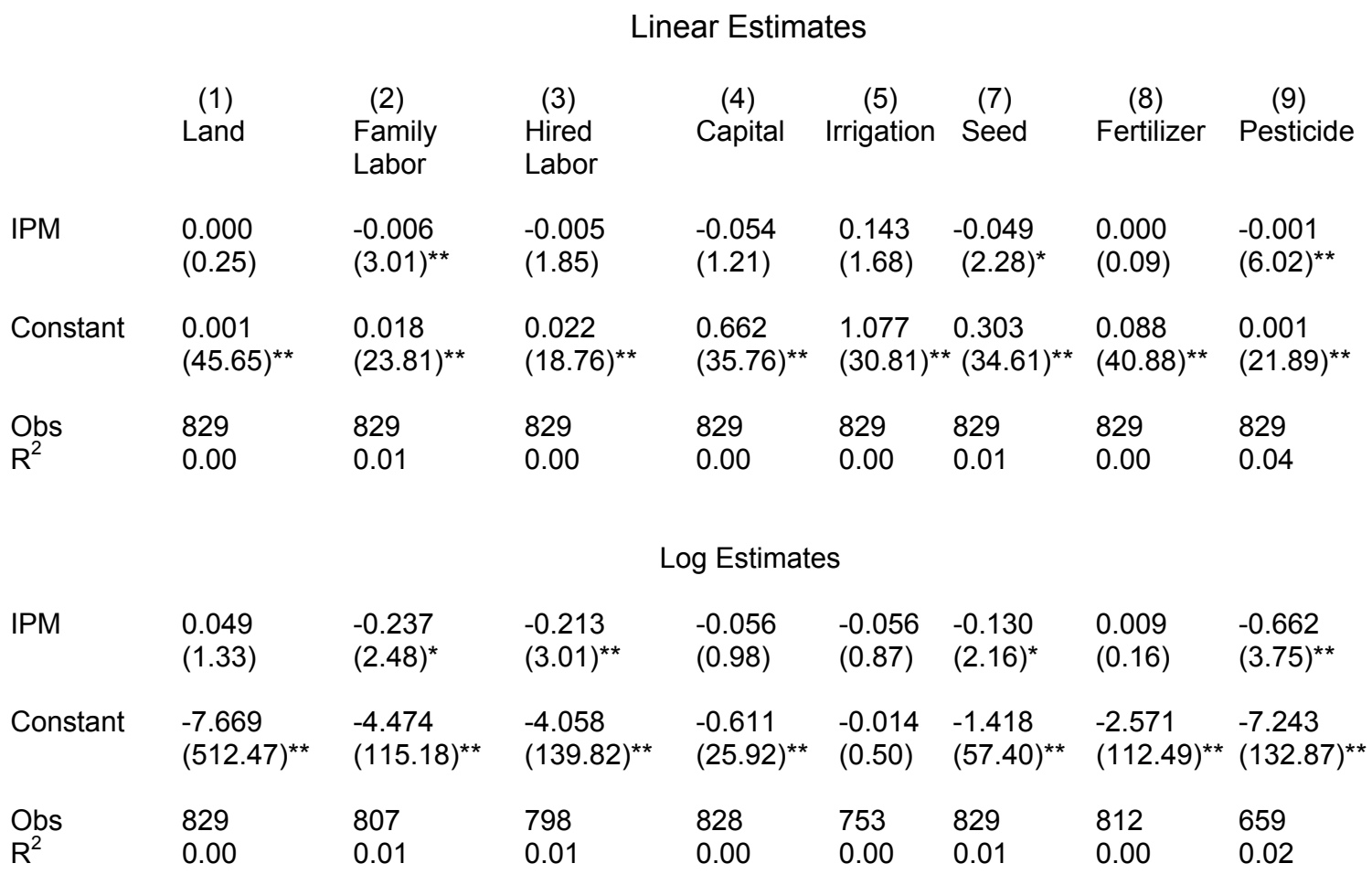

Absolute value of $t$ statistics in parentheses significant at $5 \%$; ** significant at $1 \%$

Our results suggest that IPM may be more profitable than conventional farming, since no IO coefficient is significantly higher for IPM and several are significantly lower. For pesticides, the savings are clear: Conventional farmers use an average of $2.33 \mathrm{~kg}$ of

\footnotetext{
${ }^{6}$ We have also estimated these regressions for a sample limited to the five regions where we collected data on IPM farmers, and for specifications that include the IPM determinants in Table 2. The results are indistinguishable from the full-sample estimates in Table 3.
} 
pesticides per acre, while IPM farmers use $.77 \mathrm{~kg} /$ acre. Pesticide purchase shares of variable costs for non-IPM and IPM farmers are $8.1 \%$ and $2.9 \%$, respectively.

\subsection{Cobb-Douglas Results}

We estimate a standard Cobb-Douglas production function with factor and material inputs: land, family labor, hired labor, capital, irrigation, seed and fertilizer. We include pesticide inputs and a dummy variable for IPM use in alternative specifications, since IPM explicitly minimizes pesticide use. In addition, we allow for Hicks-neutral efficiency differences across farms that are attributable to age, education, ownership, pesticide application training, farming experience, poor health, and production scale.

The production function is as follows:

$$
\ln y_{\mathrm{i}}=\beta_{\mathrm{o}}+\sum_{n=1}^{6} \beta_{n} x_{i}+\sum_{j=1}^{6} \alpha_{i} \ln z_{i}+u_{i}
$$

where

$$
\begin{aligned}
y_{\mathrm{i}}= & \text { } \\
x_{i}=\quad & \text { land (acres) } \\
& \text { labor (man-days) } \\
& \text { capital (in Taka) } \\
& \text { irrigation cost (Taka) } \\
& \text { fertilizer (kg) } \\
& \text { IPM (dummy variable: } 1 \text { if IPM; } 0 \text { otherwise) } \\
& \text { or pesticide (kg) } \\
& \text { age (years) } \\
& \text { education (categorical: } 0-4 \text { (none, primary, middle, secondary, tertiary)) } \\
& \text { ownership (1 if owner of farm; 0 otherwise) } \\
& \text { training (1 if prior training in pesticide applications; } 0 \text { otherwise) } \\
& \text { farming experience (years) } \\
& \text { poor health (1 if significant self-reported health problems; } 0 \text { otherwise) } \\
& \text { farm scale (log of total farm size in acres) }
\end{aligned}
$$

Table 4 presents estimates for equations that include IPM and pesticide use, with and without regional dummies and efficiency variables. All inputs except labor and pesticides are significant in all or most of the models. Our results suggest that the survey farmers are operating under surplus labor (zero marginal productivity) conditions for both 
Table 4: Cobb-Douglas Production Function Results

\begin{tabular}{|c|c|c|c|c|c|c|}
\hline & (1) & (2) & (3) & (4) & (5) & (6) \\
\hline Land & $\begin{array}{l}0.646 \\
(19.52)^{\star *}\end{array}$ & $\begin{array}{l}0.643 \\
(21.11)^{\star *}\end{array}$ & $\begin{array}{l}0.596 \\
(17.06)^{\star *}\end{array}$ & $\begin{array}{l}0.597 \\
(19.05)^{\star *}\end{array}$ & $\begin{array}{l}0.602 \\
(14.91)^{\star *}\end{array}$ & $\begin{array}{l}0.590 \\
(16.26)^{\star *}\end{array}$ \\
\hline Family Labor & $\begin{array}{l}-0.025 \\
(1.46)\end{array}$ & $\begin{array}{l}-0.019 \\
(1.23)\end{array}$ & $\begin{array}{l}-0.014 \\
(0.85)\end{array}$ & $\begin{array}{l}-0.005 \\
(0.32)\end{array}$ & $\begin{array}{l}-0.013 \\
(0.77)\end{array}$ & $\begin{array}{l}-0.003 \\
(0.17)\end{array}$ \\
\hline Hired Labor & $\begin{array}{l}0.022 \\
(1.18)\end{array}$ & $\begin{array}{l}0.024 \\
(1.39)\end{array}$ & $\begin{array}{l}0.025 \\
(1.29)\end{array}$ & $\begin{array}{l}0.026 \\
(1.56)\end{array}$ & $\begin{array}{l}0.026 \\
(1.35)\end{array}$ & $\begin{array}{l}0.028 \\
(1.64)\end{array}$ \\
\hline Capital & $\begin{array}{l}0.083 \\
(3.80)^{\star *}\end{array}$ & $\begin{array}{l}0.087 \\
(4.26)^{* *}\end{array}$ & $\begin{array}{l}0.064 \\
(2.88)^{\star *}\end{array}$ & $\begin{array}{l}0.070 \\
(3.43)^{\star *}\end{array}$ & $\begin{array}{l}0.067 \\
(2.99)^{\star \star}\end{array}$ & $\begin{array}{l}0.070 \\
(3.35)^{\star *}\end{array}$ \\
\hline Irrigation & $\begin{array}{l}0.115 \\
(5.56)^{\star *}\end{array}$ & $\begin{array}{l}0.094 \\
(4.97)^{\star \star}\end{array}$ & $\begin{array}{l}0.130 \\
(6.16)^{\star *}\end{array}$ & $\begin{array}{l}0.106 \\
(5.56)^{\star \star}\end{array}$ & $\begin{array}{l}0.131 \\
(6.10)^{\star *}\end{array}$ & $\begin{array}{l}0.107 \\
(5.45)^{\star \star}\end{array}$ \\
\hline Seed & $\begin{array}{l}0.040 \\
(1.87)\end{array}$ & $\begin{array}{l}0.048 \\
(2.40)^{*}\end{array}$ & $\begin{array}{l}0.036 \\
(1.68)\end{array}$ & $\begin{array}{l}0.043 \\
(2.14)^{*}\end{array}$ & $\begin{array}{l}0.038 \\
(1.77)\end{array}$ & $\begin{array}{l}0.044 \\
(2.16)^{*}\end{array}$ \\
\hline Fertilizer & $\begin{array}{l}0.088 \\
(3.66)^{\star *}\end{array}$ & $\begin{array}{l}0.074 \\
(3.29)^{\star \star}\end{array}$ & $\begin{array}{l}0.100 \\
(3.99)^{\star *}\end{array}$ & $\begin{array}{l}0.098 \\
(4.25)^{\star \star}\end{array}$ & $\begin{array}{l}0.095 \\
(3.77)^{\star *}\end{array}$ & $\begin{array}{l}0.092 \\
(3.94)^{\star \star}\end{array}$ \\
\hline Pesticide & $\begin{array}{l}-0.008 \\
(0.80)\end{array}$ & & $\begin{array}{l}0.008 \\
(0.75)\end{array}$ & & $\begin{array}{l}0.011 \\
(1.03)\end{array}$ & \\
\hline IPM & & $\begin{array}{l}-0.024 \\
(0.79)\end{array}$ & & $\begin{array}{l}-0.028 \\
(0.90)\end{array}$ & & $\begin{array}{l}-0.028 \\
(0.84)\end{array}$ \\
\hline \multicolumn{7}{|l|}{$\underline{\text { Regions }}$} \\
\hline Bogra & & & $\begin{array}{l}-0.246 \\
(3.12)^{\star \star}\end{array}$ & $\begin{array}{l}-0.224 \\
(3.20)^{\star \star}\end{array}$ & $\begin{array}{l}-0.236 \\
(2.84)^{\star \star}\end{array}$ & $\begin{array}{l}-0.230 \\
(3.11)^{\star \star}\end{array}$ \\
\hline Chapainawabganj & & & $\begin{array}{l}-0.059 \\
(0.28)\end{array}$ & $\begin{array}{l}-0.052 \\
(0.25)\end{array}$ & $\begin{array}{l}-0.059 \\
(0.28)\end{array}$ & $\begin{array}{l}-0.074 \\
(0.35)\end{array}$ \\
\hline Chittagong & & & $\begin{array}{l}0.111 \\
(1.10)\end{array}$ & $\begin{array}{l}0.110 \\
(1.09)\end{array}$ & $\begin{array}{l}0.116 \\
(1.13)\end{array}$ & $\begin{array}{l}0.125 \\
(1.22)\end{array}$ \\
\hline Comilla & & & $\begin{array}{l}-0.191 \\
(3.54)^{\star \star}\end{array}$ & $\begin{array}{l}-0.166 \\
(3.42)^{\star \star}\end{array}$ & $\begin{array}{l}-0.186 \\
(3.39)^{\star \star}\end{array}$ & $\begin{array}{l}-0.156 \\
(3.14)^{\star \star}\end{array}$ \\
\hline Jessore & & & $\begin{array}{l}-0.199 \\
(4.09)^{\star \star}\end{array}$ & $\begin{array}{l}-0.201 \\
(4.73)^{\star \star}\end{array}$ & $\begin{array}{l}-0.200 \\
(4.00)^{\star \star}\end{array}$ & $\begin{array}{l}-0.201 \\
(4.61)^{\star \star}\end{array}$ \\
\hline Kishoreganj & & & $\begin{array}{l}-0.131 \\
(2.17)^{*}\end{array}$ & $\begin{array}{l}-0.136 \\
(2.57)^{\star}\end{array}$ & $\begin{array}{l}-0.135 \\
(2.20)^{\star}\end{array}$ & $\begin{array}{l}-0.134 \\
(2.48)^{\star}\end{array}$ \\
\hline Munshiganj & & & $\begin{array}{l}0.171 \\
(1.70)\end{array}$ & $\begin{array}{l}0.154 \\
(1.65)\end{array}$ & $\begin{array}{l}0.181 \\
(1.76)\end{array}$ & $\begin{array}{l}0.148 \\
(1.55)\end{array}$ \\
\hline Narsingdi & & & $\begin{array}{l}-0.191 \\
(3.50)^{\star *}\end{array}$ & $\begin{array}{l}-0.149 \\
(3.04)^{\star *}\end{array}$ & $\begin{array}{l}-0.200 \\
(3.57)^{\star *}\end{array}$ & $\begin{array}{l}-0.151 \\
(2.98)^{\star \star}\end{array}$ \\
\hline Mymensingh & & & $\begin{array}{l}-0.148 \\
(2.81)^{\star \star}\end{array}$ & $\begin{array}{l}-0.156 \\
(3.20)^{\star \star}\end{array}$ & $\begin{array}{l}-0.161 \\
(3.02)^{\star *}\end{array}$ & $\begin{array}{l}-0.164 \\
(3.28)^{\star \star}\end{array}$ \\
\hline Rajshahi & & & $\begin{array}{l}-0.266 \\
(5.44)^{\star *}\end{array}$ & $\begin{array}{l}-0.287 \\
(6.32)^{\star *}\end{array}$ & $\begin{array}{l}-0.268 \\
(5.39)^{* *}\end{array}$ & $\begin{array}{l}-0.291 \\
(6.27)^{\star \star}\end{array}$ \\
\hline \multicolumn{7}{|l|}{ Efficiency Factors } \\
\hline Age & & & & & $\begin{array}{l}-0.000 \\
(0.14)\end{array}$ & $\begin{array}{l}-0.000 \\
(0.25)\end{array}$ \\
\hline Education & & & & & $\begin{array}{l}-0.022 \\
(1.84)\end{array}$ & $\begin{array}{l}-0.011 \\
(1.03)\end{array}$ \\
\hline Ownership & & & & & $\begin{array}{l}0.049 \\
(1.29)\end{array}$ & $\begin{array}{l}0.048 \\
(1.31)\end{array}$ \\
\hline Training & & & & & $\begin{array}{l}0.029 \\
(0.48)\end{array}$ & $\begin{array}{l}0.009 \\
(0.15)\end{array}$ \\
\hline Experience & & & & & $\begin{array}{l}-0.002 \\
(1.04)\end{array}$ & $\begin{array}{l}-0.001 \\
(0.49)\end{array}$ \\
\hline Health & & & & & $\begin{array}{l}-0.020 \\
(0.75)\end{array}$ & $\begin{array}{l}-0.025 \\
(1.03)\end{array}$ \\
\hline Farm Scale & & & & & $\begin{array}{l}-0.013 \\
(0.39)\end{array}$ & $\begin{array}{l}0.011 \\
(0.36)\end{array}$ \\
\hline Constant & $\begin{array}{l}5.517 \\
(25.04)^{\star *}\end{array}$ & $\begin{array}{l}5.664 \\
(28.38)^{\star *}\end{array}$ & $\begin{array}{l}5.620 \\
(25.76)^{\star *}\end{array}$ & $\begin{array}{l}5.700 \\
(29.19)^{\star *}\end{array}$ & $\begin{array}{l}5.626 \\
(24.60)^{\star *}\end{array}$ & $\begin{array}{l}5.717 \\
(27.63)^{* *}\end{array}$ \\
\hline Observations & 569 & 697 & 569 & 697 & 569 & 693 \\
\hline $\mathrm{R}^{2}$ & 0.89 & 0.88 & 0.90 & 0.89 & 0.90 & 0.89 \\
\hline
\end{tabular}

Absolute value of $t$ statistics in parentheses

${ }^{*}$ significant at $5 \%$; ${ }^{* *}$ significant at $1 \%$ 
family and hired labor. We also find no evidence of positive productivity for pesticide use, possibly because direct benefits of pesticides are counteracted by their toxic impact on beneficial soil organisms and insects that prey on pests. We obtain functionallyequivalent results for the IPM dummy: Farmers who reduce pesticide use by adopting IPM are neither more nor less productive than conventional farmers, ceteris paribus. This result is not affected by the inclusion of regional dummies and efficiency-related variables. Many of the former are highly significant, suggesting important roles for local soil and weather conditions, while we find no significance for any of the variables that were hypothesized to affect efficiency as well as IPM adoption.

\subsection{Stochastic Production Frontier Estimation}

For a more sophisticated assessment of conventional and IPM methods, we use the stochastic production frontier methodology developed by Battese and Coelli (1993, 1995). The general stochastic production function, with inefficiency effects, is defined as:

$$
y_{i}=f\left(x_{i} ; \beta\right) \exp \left(v_{i}-u_{i}\right) \quad i=1, \ldots, \mathrm{n}
$$

where $y_{i}$ denotes the output quantity of the $i$ th farm, $x_{i}$ is a $(1 \times J)$ vector of input quantities and $\beta$ is a $(J \times 1)$ vector of unknown parameters to be estimated. The $v_{i}$ are two-sided random variables associated with measurement errors in output and are assumed to be independently and identically distributed $N\left(0, \sigma_{v}^{2}\right)$ and independent of the $u_{i}$. In the absence of the stochastic term $u_{i}$, the model in (1) reduces to a purely deterministic (mean) production function. The $u_{i}$ are defined as non-negative random variables which account for technical inefficiency effects in production and are independently distributed as truncations at zero of the $N\left(\mu_{i}, \sigma_{u}^{2}\right)$ distribution, where:

$$
\mu_{i}=\delta_{o}+\sum_{k=1}^{K} \delta_{k} z_{i k}+\omega_{i}
$$

and $z_{i}$ is a $(1 \times K)$ vector of farm characteristics that affect efficiency and $\delta$ is an $(K \times 1)$ vector of parameters to be estimated. The $\omega_{i}$ 's are random variables generally defined by the truncation of the normal distribution with zero mean and variance $\sigma^{2}$, with the point of truncation as $\omega_{i} \geq-\delta z_{i}$.

Maximum likelihood methods are used to simultaneously estimate the stochastic frontier and technical inefficiency effects models. For the likelihood function. the 
variance terms are parameterized as $\sigma^{2}=\sigma_{v}^{2}+\sigma_{u}^{2}$ and $\gamma=\sigma_{u}^{2} /\left(\sigma_{v}^{2}+\sigma_{u}^{2}\right)$, with $0 \leq \gamma \leq 1$

(Battese and Coelli, 1995). Technical inefficiency for the $i$-th farm is estimated as the expectation of $u_{i}$, conditional on the observed value of $\left(v_{i}-u_{i}\right)$ :

$$
T E_{i}=E\left[\exp \left(-u_{i}\right) \mid v_{i}-u_{i}\right]=E\left[\exp \left(-\delta_{o}-\sum_{k=1}^{K} \delta_{k} z_{i k}-\omega_{i}\right) \mid v_{i}-u_{i}\right]
$$

\subsection{Alternative Production Functions}

For the production function in equation (1), we begin with the translog specification:

$$
\ln y_{\mathrm{i}}=\beta_{\mathrm{o}}+\sum_{n=1}^{8} \beta_{n} \ln x_{i}+\frac{1}{2} \sum_{n=1}^{8} \sum_{k=1}^{8} \beta_{n k} \ln x_{i n} \ln x_{i k}+v_{i}-u_{i}
$$

where

$$
\begin{aligned}
y_{\mathrm{i}}= & \text { represents the quantity of rice output (in } \mathrm{kg}) \\
x_{i}= & \text { land (acres) } \\
& \text { family labor (man-days) } \\
& \text { hired labor (man-days) } \\
& \text { capital (in Taka) } \\
& \text { irrigation cost (Taka) } \\
& \text { seed cost (Taka) } \\
& \text { fertilizer (kg) } \\
& \text { pesticide (kg) } \\
& \text { IPM (dummy variable: } 1 \text { if IPM; } 0 \text { otherwise) }
\end{aligned}
$$

We specify the technical inefficiency model as:

$$
\mu_{i}=\delta_{o}+\sum_{k=1}^{K} \delta_{k} z_{i k}+\omega_{i}
$$

where

$$
\begin{aligned}
z_{i}= & \text { age (years) } \\
& \text { education (categorical: 0-4 (none, primary, middle, secondary, tertiary)) } \\
& \text { farm size (total acres) } \\
& \text { farming experience (years) } \\
& \text { ownership ( } 1 \text { if owner of farm; } 0 \text { otherwise) } \\
& \text { training ( } 1 \text { if trained in applying and safe handling of pesticides; } 0 \text { otherwise) } \\
& \text { health status ( } 1 \text { if significant health problems; } 0 \text { otherwise) }
\end{aligned}
$$

Appendix II provides more precise variable definitions and descriptive statistics. 


\subsection{Estimation results}

We obtained maximum likelihood estimates for the parameters using the Frontier 4.1 program (Coelli, 1996), and ran several likelihood ratio (LR) tests on the functional form, the stochastic specification and inefficiency effects (Table 5). ${ }^{7}$ We report full results in Table 6. In row 1 of Table 5, we test the null hypothesis on the joint translog restrictions implied by the Cobb-Douglas specification. We find that the restrictions cannot be rejected at a very high confidence level, so we adopt the Cobb-Douglas form because its constant-elasticity results are more easily interpreted.

\section{Table 5. Tests of Hypotheses}

\begin{tabular}{|c|c|c|c|c|c|c|c|}
\hline \multirow[t]{2}{*}{ Null hypothesis } & \multirow[t]{2}{*}{ Restrictions } & \multicolumn{6}{|c|}{ Log-Likelihood } \\
\hline & & (Ho) & $\left(\mathbf{H}_{1}\right)$ & $\lambda$ & \# restr. & $\begin{array}{l}\text { Critical } \\
\text { value }\end{array}$ & Outcome \\
\hline \multicolumn{8}{|l|}{ Functional form } \\
\hline Cobb-Douglas & $\beta_{n k}=0 \quad \forall \mathrm{k}, \forall \mathrm{n}$ & -94.274 & -54.790 & 78.970 & 36 & 47.212 & Reject Ho at $10 \%$ \\
\hline \multicolumn{8}{|c|}{ Mean function (OLS) } \\
\hline Cobb-Douglas & $\gamma=\delta_{\mathrm{o}}=\delta_{1}=\ldots=\delta_{9}=0$ & -113.525 & -94.274 & 38.501 & 12 & 25.549 & Reject Ho at $1 \%$ \\
\hline \multicolumn{8}{|c|}{ Accounting for inefficiency effects } \\
\hline Cobb-Douglas & $\delta_{1}=\ldots=\delta_{9}=0$ & -113.525 & -94.274 & 38.502 & 11 & 24.725 & Reject Ho at $1 \%$ \\
\hline
\end{tabular}

Row 2 tests the estimated stochastic frontier against the mean function estimated by ordinary least squares: Under $H_{\mathrm{o}}$ the error term $u$ is assumed to be non-stochastic and equal to zero. Failure to reject $H_{\mathrm{o}}$ implies that deviations from the frontier are purely random, and that variables chosen to model inefficiency effects can enter directly into the production function for estimation by ordinary least squares. Our LR test rejects $H_{\mathrm{o}}$ with high confidence, implying that deviations from the frontier are systematic in Bangladeshi farming. ${ }^{8}$

${ }^{7}$ The likelihood ratio test is $\lambda=-2\left[\ln L F\left(H_{\mathrm{o}}\right)-\ln L F\left(H_{1}\right)\right]$, where $L F$ denotes the likelihood function, $H_{\mathrm{o}}$ the null hypothesis and $H_{1}$ the alternative hypothesis. $\lambda$ follows a chi-squared distribution with the number of degrees of freedom equal to the number of restrictions. Estimation results report the parameters $\sigma^{2}=\sigma_{u}^{2}+\sigma_{v}^{2}$ and $\gamma=\sigma_{u}{ }^{2} /\left(\sigma_{u}^{2}+\sigma_{v}^{2}\right)$, where $\sigma^{2}$ corresponds to the variance of the overall model, and $\gamma$ is the share of inefficiency variance to overall model variance. Since $\gamma$ is the ratio of two variances, and is therefore always positive, the test statistic follows a mixed chi-square distribution, with the critical values to be found in Kodde and Palme (1996).

8 This result can be confirmed via the estimated value of $\gamma(0.17$ in Table 6 , where $\gamma=1$ implies no random noise) and the calculated variance-ratio parameter $\gamma^{*}(0.07)$. This implies that only $7 \%$ of the difference between observed and frontier output is due to differences in farmer efficiency. Statistical significance for $\gamma$ implies that distributional variation in $u$ can be systematically explained by the regressors in the inefficiency model. Although $\gamma$ is not significant, the likelihood ratio test above suggested a mild effect. 
Row 3 tests whether the variables in our inefficiency effects model (equation 5) have joint significance in explaining farmer inefficiency. Rejection of the null at the $1 \%$ level indicates that farmer inefficiency is significantly associated with differences in farmers age, education, farm size, experience, ownership, training, health and regional conditions.

Table 6 reports estimates for the translog and Cobb-Douglas models, with and without controls for IPM use. Since we cannot reject the translog constraints implied by the Cobb-Douglas specification, we focus on results for the latter because they are easily interpreted as elasticities. Our results suggest that land is easily the most significant factor in Bangladeshi rice production. In the Cobb-Douglas estimate with a single dummy control for IPM, a $1 \%$ increase in land under production translates into a $0.57 \%$ increase in rice output. The two labor variables, family and hired, are insignificant, with a small negative elasticity in the case of family labor. The very small, insignificant elasticities for labor may imply that rice production is currently in a condition of surplus (zero-marginal-productivity) labor. Capital is also significant, although the estimate implies that a $1 \%$ increase in capital is only associated with a $0.08 \%$ increase in rice output. Irrigation appears to play a significant role, as do seed inputs, although to a lesser degree. Fertilizers also make a significant contribution to rice production, with an elasticity of 0.11 . However, pesticides do not have any significant effect, suggesting that potential incremental gains are neutralized by toxic soil saturation or elimination of beneficial soil organisms and insect predators. The sum of input elasticities $\left(\Sigma \beta_{n}=0.92\right)$ suggests modestly-decreasing returns to scale, a finding similar to other results in the frontier production estimation literature (Coelli, Rahman and Thirtle, 2002; Wadud and White, 2000).

To measure the contribution of inefficiency variance to overall frontier variance, we use $\gamma^{*}=\tilde{\gamma}[\gamma+(1-$ $\gamma) \pi /(\pi-2)]$ (Coelli, Rao and Battese, 1998). For the Cobb-Douglas model, this is equal to $7 \%$. 
Table 6. Maximum-likelihood estimates of the stochastic production frontier model

\begin{tabular}{|c|c|c|c|c|c|c|c|}
\hline \multirow[b]{2}{*}{ Variable } & \multirow[b]{2}{*}{ Parameters } & \multicolumn{2}{|l|}{ Translog } & \multicolumn{2}{|c|}{ Cobb-Douglas } & \multicolumn{2}{|c|}{ Cobb-Douglas + IPM } \\
\hline & & Coefficients & t-ratio & Coefficients & t-ratio & Coefficients & t-ratio \\
\hline Constant & $\beta_{\mathrm{o}}$ & 13.992 & $9.030 * * *$ & 5.592 & $24.266 * * *$ & 5.617 & $13.742 * * *$ \\
\hline Land & $\beta_{L}$ & 3.257 & $6.329 * * *$ & 0.570 & $14.935 * * *$ & 0.615 & $8.308 * * *$ \\
\hline Family labor & $\beta_{F L}$ & -0.447 & -1.490 & -0.016 & -0.889 & -0.015 & -0.628 \\
\hline Hired labor & $\beta_{H L}$ & -0.253 & -0.693 & 0.026 & 1.244 & 0.048 & $1.751 *$ \\
\hline Capital & $\beta_{C}$ & -1.410 & $-4.000 * * *$ & 0.076 & $3.184 * * *$ & 0.056 & $1.864 *$ \\
\hline Irrigation & $\beta_{I}$ & 0.191 & 0.576 & 0.115 & $5.244 * * *$ & 0.124 & $4.306 * * *$ \\
\hline Seed & $\beta_{S}$ & -0.201 & -0.405 & 0.042 & $1.918 *$ & 0.037 & 1.466 \\
\hline Fertilizer & $\beta_{F}$ & -0.552 & -1.154 & 0.111 & $4.173 * * *$ & 0.090 & $2.422 * *$ \\
\hline Pesticide & $\beta_{P}$ & -0.142 & -0.790 & 0.001 & 0.096 & 0.002 & 0.070 \\
\hline Land $x$ Land & $\beta_{L L}$ & 0.477 & $4.329 * * *$ & & & & \\
\hline Fam lab x Fam lab & $\beta_{F L F L}$ & -0.011 & -0.400 & & & & \\
\hline Hire lab x Hire lab & $\beta_{H L H L}$ & 0.016 & 0.591 & & & & \\
\hline Capital x Capital & $\beta_{C C}$ & 0.090 & $2.052 * *$ & & & & \\
\hline Irrigation $\mathrm{x}$ Irrigation & $\beta_{I I}$ & 0.037 & 0.923 & & & & \\
\hline Seed $x$ Seed & $\beta_{S S}$ & -0.016 & -0.296 & & & & \\
\hline Fertilizer x Fertilizer & $\beta_{F F}$ & 0.125 & $2.188 * *$ & & & & \\
\hline Pesticide x Pesticide & $\beta_{P P}$ & 0.016 & 1.161 & & & & \\
\hline Land $x$ Fam lab & $\beta_{L F L}$ & -0.099 & $-2.119 * *$ & & & & \\
\hline Land $x$ Hire lab & $\beta_{L H L}$ & -0.144 & $-2.672 * * *$ & & & & \\
\hline Land $x$ Capital & $\beta_{L C}$ & -0.166 & $-3.034 * * *$ & & & & \\
\hline Land $x$ Irrigation & $\beta_{L I}$ & 0.039 & 0.851 & & & & \\
\hline Land $x$ Seed & $\beta_{L S}$ & -0.100 & -1.566 & & & & \\
\hline Land $x$ Fertilizer & $\beta_{L F}$ & -0.074 & -0.994 & & & & \\
\hline Land $x$ Pesticide & $\beta_{L P}$ & -0.018 & -0.689 & & & & \\
\hline Fam lab x Hire lab & $\beta_{F L H L}$ & -0.028 & -1.135 & & & & \\
\hline Fam lab x Capital & $\beta_{F L C}$ & 0.058 & $1.816^{*}$ & & & & \\
\hline Fam lab x Irrigation & $\beta_{F L I}$ & -0.006 & -0.221 & & & & \\
\hline Fam lab x Seed & $\beta_{F L S}$ & -0.015 & -0.484 & & & & \\
\hline Fam lab x Fertilizer & $\beta_{F L F}$ & 0.056 & 1.611 & & & & \\
\hline Fam lab x Pesticide & $\beta_{F L P}$ & 0.007 & 0.536 & & & & \\
\hline Hire lab x Capital & $\beta_{H L C}$ & 0.054 & 1.515 & & & & \\
\hline Hire lab x Irrigation & $\beta_{H L I}$ & -0.035 & -1.158 & & & & \\
\hline Hire lab x Seed & $\beta_{H L S}$ & 0.008 & 0.234 & & & & \\
\hline Hire lab x Fertilizer & $\beta_{H L F}$ & 0.033 & 0.811 & & & & \\
\hline Hire lab x Pesticide & $\beta_{H L P}$ & 0.018 & 1.325 & & & & \\
\hline Capital x Irrigation & $\beta_{C I}$ & 0.045 & 1.207 & & & & \\
\hline Capital x Seed & $\beta_{C S}$ & 0.025 & 0.693 & & & & \\
\hline Capital x Fertilizer & $\beta_{C F}$ & -0.005 & -0.130 & & & & \\
\hline Capital x Pesticide & $\beta_{C P}$ & -0.016 & -0.824 & & & & \\
\hline Irrigation $\mathrm{x}$ Seed & $\beta_{I S}$ & -0.018 & -0.412 & & & & \\
\hline Irrigation $\mathrm{x}$ Fertilizer & $\beta_{I F}$ & -0.082 & $-2.046 * *$ & & & & \\
\hline Irrigation $\mathrm{x}$ Pesticide & $\beta_{I P}$ & 0.029 & $1.711 *$ & & & & \\
\hline Seed $x$ Fertilizer & $\beta_{S F}$ & 0.066 & 1.540 & & & & \\
\hline Seed $x$ Pesticide & $\beta_{S P}$ & -0.006 & -0.336 & & & & \\
\hline Fertilizer x Pesticide & $\beta_{F P}$ & -0.003 & -0.149 & & & & \\
\hline IPM & $\beta_{I P M}$ & -0.050 & -1.071 & -0.039 & -0.824 & 0.893 & 0.892 \\
\hline Land $x$ IPM & $\beta_{L x I P M}$ & & & & & 0.150 & 1.118 \\
\hline Family labor x IPM & $\beta_{F L x I P M}$ & & & & & -0.003 & -0.043 \\
\hline Hired labor x IPM & $\beta_{H L x I P M}$ & & & & & -0.102 & $-1.846 *$ \\
\hline Capital x IPM & $\beta_{C x I P M}$ & & & & & 0.032 & 0.411 \\
\hline Irrigation $\mathrm{x}$ IPM & $\beta_{I x I P M}$ & & & & & -0.052 & -0.610 \\
\hline Seed x IPM & $\beta_{S x I P M}$ & & & & & 0.005 & 0.050 \\
\hline
\end{tabular}




\begin{tabular}{|c|c|c|c|c|c|c|c|}
\hline Fertilizer x IPM & $\beta_{F x I P M}$ & & & & & -0.078 & -0.913 \\
\hline Pesticide $\mathrm{x}$ IPM & $\beta_{P \times I P M}$ & & & & & 0.016 & 0.514 \\
\hline \multicolumn{8}{|l|}{ Inefficiency effects } \\
\hline Constant & $\delta_{\mathrm{o}}$ & -0.780 & $-2.295 * *$ & -0.175 & -1.076 & -0.545 & -1.644 \\
\hline Age & $\delta_{A}$ & 0.002 & 0.456 & 0.001 & 0.202 & 0.001 & 0.225 \\
\hline Education & $\delta_{E}$ & 0.012 & 0.411 & 0.022 & 1.062 & 0.007 & 0.302 \\
\hline Owner & $\delta_{O}$ & 0.012 & 0.142 & 0.041 & 0.607 & 0.034 & 0.279 \\
\hline Training & $\delta_{T}$ & -0.044 & -0.307 & -0.047 & -0.432 & -0.105 & -0.415 \\
\hline Experience & $\delta_{\text {Exper }}$ & 0.000 & 0.048 & 0.001 & 0.253 & 0.000 & -0.306 \\
\hline Health & $\delta_{\text {Health }}$ & 0.010 & 0.183 & 0.043 & 1.080 & 0.018 & 0.577 \\
\hline Farm scale & $\delta_{\text {Farm scale }}$ & 0.006 & 0.322 & -0.028 & $-1.712 *$ & 0.006 & 0.346 \\
\hline Bogra & $\delta_{\text {Bogra }}$ & 0.934 & $2.087 * *$ & 0.387 & $2.854 * * *$ & 0.624 & $4.428 * * *$ \\
\hline Chapinawabganj & $\delta_{\text {Chapi }}$ & -0.247 & -0.244 & -0.741 & -0.700 & -0.157 & -0.220 \\
\hline Chittagong & $\delta_{\text {Chitta }}$ & -0.080 & -0.161 & -0.102 & -0.459 & -0.149 & -0.464 \\
\hline Comilla & $\delta_{\text {Comilla }}$ & 0.812 & $1.713 *$ & 0.304 & $2.835 * * *$ & 0.553 & $4.424 * * *$ \\
\hline Jessore & $\delta_{\text {Jessore }}$ & 0.831 & $1.693 *$ & 0.330 & $3.137 * * *$ & 0.549 & $4.877 * * *$ \\
\hline Kishoreganj & $\delta_{\text {Kishor }}$ & 0.658 & 0.998 & 0.228 & $1.828 *$ & 0.446 & $2.298 * *$ \\
\hline Munshiganj & $\delta_{\text {Munsh }}$ & -0.312 & -0.538 & -0.224 & -1.174 & -0.165 & -0.842 \\
\hline Narshingdi & $\delta_{\text {Narsh }}$ & 0.798 & 1.604 & 0.342 & $3.084 * * *$ & 0.537 & $4.484 * * *$ \\
\hline Mymensingh & $\delta_{\text {Mymen }}$ & 0.794 & 1.600 & 0.332 & $3.019 * * *$ & 0.479 & $4.110 * * *$ \\
\hline Rajshahi & $\delta_{\text {Rajshahi }}$ & 0.948 & $2.415 * *$ & 0.452 & $4.600 * * *$ & 0.651 & $6.396 * * *$ \\
\hline \multicolumn{8}{|l|}{ Variance parameters } \\
\hline Sigma-squared & $\sigma^{2}=\sigma_{\mathrm{u}}^{2}+{\sigma_{\mathrm{v}}}^{2}$ & 0.078 & $4.396 * * *$ & 0.086 & $9.130 * * *$ & 0.078 & $13.354 * * *$ \\
\hline Gamma & $\gamma=\sigma_{u}^{2} /\left(\sigma_{u}^{2}+\sigma_{v}^{2}\right)$ & 0.190 & 0.721 & 0.171 & 1.144 & 0.066 & 0.972 \\
\hline Log-likelihood & & -54.790 & & -94.274 & & -74.755 & \\
\hline Number of observations & & 569 & & 569 & & 569 & \\
\hline
\end{tabular}

Note: $*, * *, * *$ - significant at the $10 \%, 5 \%$, and $1 \%$ level, respectively.

In no case do we find significance for IPM, whether it enters as a single control (dummy variable) or interacted with each input (with the single exception of hired labor). We also find no significance for other hypothesized inefficiency factors. The overall significance of the regional dummies suggests that local environmental and geographic factors may have important effects on farmer inefficiency. ${ }^{9}$

Table 7 presents statistics for farm-level technical efficiency scores estimated by the model. Mean technical efficiency across farms is $83 \%$, with variation from a minimum of $63 \%$ to over $98 \%$. The distribution of scores is fairly central, with $65 \%$ of the farmers around $75-90 \%$ efficient and a fairly uniform distribution (20\%) above and below this range of technical efficiency. Other studies of Bangladesh rice farming have yielded similar average efficiency scores (Coelli, Rahman and Thirtle, 2002; Rahman, 2003; Wadud and White, 2000). These results imply that, on average, farmers can increase rice

\footnotetext{
${ }^{9}$ For example, soil quality attributes would be one area for further investigation.
} 
output, and thus increase profits, by approximately $17 \%(100-83 \%)$ by improving technical, allocative and scale efficiency in production.

\begin{tabular}{|c|c|c|c|}
\hline Efficiency score & $\begin{array}{c}\text { No. } \\
\text { of farms }\end{array}$ & $\begin{array}{c}\% \\
\text { of farms }\end{array}$ & Cumulative \\
\hline $0-25$ & 0 & 0.0 & 0.0 \\
\hline $25-50$ & 0 & 0.0 & 0.0 \\
\hline $50-75$ & 83 & 14.6 & 14.6 \\
\hline $75-90$ & 371 & 65.2 & 79.8 \\
\hline $90-95$ & 58 & 10.2 & 90.0 \\
\hline $95-100$ & 57 & 10.0 & 100.0 \\
\hline Total & 569 & 100.0 & \\
\hline \multicolumn{4}{|l|}{ Summary statistics } \\
\hline Mean & 83.0 & & \\
\hline Min & 62.9 & & \\
\hline Max & 98.6 & & \\
\hline Standard deviation & 7.5 & & \\
\hline Coefficient of variation & 9.1 & & \\
\hline
\end{tabular}

\section{Health Effects of IPM Adoption}

Our survey results suggest that farmers' exposure to toxic pesticides is quite serious in Bangladesh, ${ }^{10}$ while our productivity analysis suggests that any direct benefits from pesticide use have been offset by adverse impacts on soil organisms, natural pest predators, and farmers' health and productivity (Rola and Pingali, 1993). Exposure can produce numerous acute effects, depending on a pesticide's toxicity and the dose absorbed by the body. For pesticides with high acute toxicity, exposure can produce intoxication symptoms within minutes or hours, including headaches, flu-like symptoms, skin rashes, blurred vision, and other neurological disorders (World Resources, 1998-99). Prolonged exposure can lead to more serious cardiopulmonary, neurological and hematological symptoms, as well as skin disease (Davies, Freed, and Whittemore, 1982; Spear, 1991).

${ }^{10}$ A distinctive feature of pesticide-related health hazards is that the magnitude of the health effect associated with pesticide use can often be reduced by averting behavior - wearing protective clothing, such as gloves or a jacket. Such measures can often reduce exposure by up to 80 or 90 percent (Cropper, 1994). However, during the study, applicators of pesticides communities were rarely found to be wearing proper protective clothing. 
A detailed health examination of farmers in our survey ${ }^{11}$ was beyond the scope of this study. Instead, our analysis relies on self-reported health effects. Among conventional farmers, $37 \%$ report frequent health problems such as eye irritation, headaches, dizziness, vomiting, shortness of breath, skin effects, and convulsions. ${ }^{12}$ Among IPM farmers, 29\% report similar health problems. Of these, 54\% report that the health of the laborers working in their fields improved after they switched to IPM.

Although IPM farmers have a lower reported incidence of health effects, we find that the difference between the two groups is not significant at the $95 \%$ confidence level. The difference may be greater for farmers who have used IPM for an extended period, but our survey has not recorded IPM adoption dates. For more recent adopters, our result may be biased by a simultaneous relationship between IPM use and health: Adoption of IPM may well improve health, even in the short run, but farmers who attribute their poor health to pesticide use may be more likely to adopt IPM. At present, we do not have sufficient evidence to attribute strong health improvements to IPM adoption in our sample.

\section{Environmental Effects}

Recent evidence suggests that pesticide use in Bangladesh has damaged organisms not targeted by applications ${ }^{13}$, while pesticide runoff has polluted many waterways. ${ }^{14}$ Much of the damage can be attributed to the timing, frequency and dose-intensity of applications, as well as use of inappropriate products and lack of information about

11 This would include a comprehensive physical examination, blood cholinesterase determination and skin patch tests.

${ }^{12}$ Are self-reported health effects a credible measure? Suggestive evidence is provided by medical tests of the farming population in other Asian countries. Several clinical studies conducted on rice and vegetable farmers in Indonesia, Philippines, and Vietnam revealed that $58 \%$ - 99\% of the farmers exposed to pesticides had at least one health effect (Xuyen et al., 1998; Kishi et al, 1995; Antle and Pingali, 1994; Rola and Pingali, 1993). This evidence suggests that the degree of upward bias, if any, in the self-assessment of health effects may not be large.

${ }^{13}$ For example, a number of newspapers in Bangladesh (Manab Zamin, September 6, 1999; Bhorer Kagaz, September 1, 1999; Inqilab, September 2, 1999) reported the poisoning and death of thousands of birds in Ustad by Cypermethrin- treated eggplant fields in the Dakatia village of Jessore, a district in the Western border region of Bangladesh (UBINIG, 1999).

${ }^{14}$ A government study conducted in 1995 found that $11 \%$ of tested water samples contained pesticide residues higher than WHO guidelines (Government of Bangladesh, 1995). 
toxicity. When asked about environmental effects, nearly $70 \%$ of the IPM farmers in our survey report improvements in soil, water and air quality after adoption of IPM (Figure 3 ), as well as increased numbers birds, fish and soil organisms such as earthworms.

Figure 3. Observed change in soil, water and air quality after IPM adoption

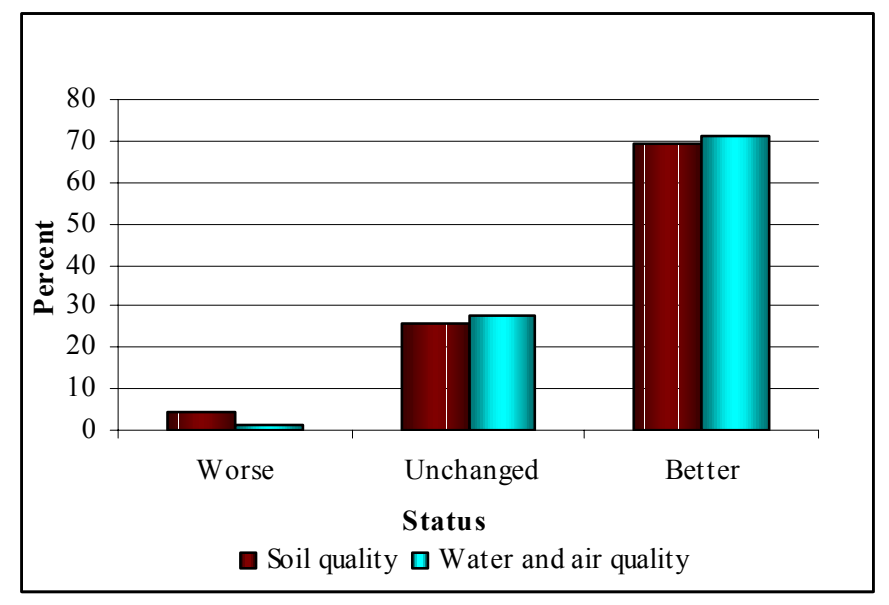

\section{Summary and Conclusions}

In this paper, we have used new survey data on rice production to assess the net economic, health and environmental benefits of switching to Integrated Pest Management in Bangladesh. We have assessed the net economic benefits of IPM adoption in three productivity comparisons, using input ratios, standard production functions and stochastically-estimated production frontiers. In all three cases, we have found no significant difference in productivity for IPM and non-IPM rice farming. Our results hold when we control for hypothesized farm-efficiency factors that also affect the probability of IPM adoption. Our evidence suggests that IPM adoption increases profits for rice farmers, since pesticide costs are reduced with no countervailing reduction in output. The reported incidence of sickness is lower for IPM farmers, although the difference is not statistically significant in our sample. Most IPM farmers also report that environmental conditions improved after adoption of the new technique.

To summarize, our evidence suggests that further promotion of Integrated Pest Management for Bangladeshi rice farmers will yield economic, health and environmental benefits for rural communities. As we have noted, local adoption of IPM is a collective decision because farmers' pesticide applications affect their neighbors' fields as well. 
Effective promotion strategies should therefore emphasize collective gains from adoption, as well as training of individual farmers in the relevant skills. 


\section{References}

Antle, J.M. and P.L. Pingali, 1994. Pesticides, Productivity, and Farmer Health: A Philippine Case Study. American Journal of Agricultural Economics 76: 418-430.

Bangladesh Bureau of Statistics (BBS), 2001. Statistical Yearbook of Bangladesh, December 2003, Planning Division, Ministry of Planning, Government of the Peoples Republic of Bangladesh.

Battese, G. and T. Coelli, 1995. A Model for Technical Efficiency Effects in a Stochastic Frontier Production Function for Panel Data. Empirical Economics 20: 325-332.

Coelli,T., 1996. FRONTIER Version 4.1: A Computer Program for Stochastic Frontier Production and Cost Function Estimation. Department of Econometrics, University of New England, Armidale, NSW.

Coelli, T., S. Rahman and C. Thirtle, 2002. Technical, Allocative, Cost and Scale Efficiencies in Bangladesh Rice Cultivation: A Non-parametric Approach. Journal of Agricultural Economics 53: 607-626.

Coelli, T., D. S. P. Rao and G. E. Battese, 1998. An Introduction to Efficiency and Productivity Analysis. Kluwer Academic Publishers: Boston, MA.

Cropper, M., 1994. Economic and Health Consequences of Pesticide Use in Developing Country Agriculture: Discussion. American Journal of Agricultural Economics 76: 605-607.

Davies, V., H. Freed and F. W. Whittemore, 1982. An Agromedical Approach to Pesticide Management: Some Health and Environmental Considerations. Miami, Fla., USA: University of Miami School of Medicine in cooperation with the Agency for International Development (USAID) and Consortium for International Crop Protection.

Dinham, B., 1993. The Pesticide Hazard: A Global Health and Environmental Audit, London: Zed Books.

FAO, 2001. Bangladesh Country Report on IPM. FAO Intercountry Programme on Integrated Pest Management. Report to the Programme Advisory Committee, November. Available at: http://www.communityipm.org/docs/PAC_2001/Bangladesh_PAC2001.pdf

Government of Bangladesh, 1995. Baseline Survey Water Quality. Ministry of Agriculture. National Minor Irrigation Development Project, Dhaka. (pg. 29)

Hossain, M., 1988. Nature and Impact of the Green Revolution in Bangladesh. Research Report No. 67. Washington, D.C.: International Food Policy Research Institute. 
Kishi, M., N. Hirschhorn, M. Qjajadisastra, L. N. Satterlee, S. Strowman and R. Dilts, 1995. Relationship of Pesticide Spraying to Signs and Symptoms in Indonesian Farmers, Scandinavian Journal of Work \& Environmental Health, 21: 124-133.

Kodde, D., F. Palm, 1986. Wald Criteria for Jointly Testing Equality and Inequality Restrictions. Econometrica 54: 1243-1248.

NOVIB, 1993. Pesticides Misuse in Bangladesh, The Pesticides News, No. 22, Dec. 1993. The Pesticides Trust. London, U.K.

Rahman, S., 2003. Profit Efficiency among Bangladeshi Rice Farmers. Food Policy 28: 487-503.

Ramaswamy, 1992. Pest control and Environment, notes for discussion at a seminar on environment and agriculture. Agriculturalist Association of Bangladesh, Dhaka, p.19.

Rasul and Thapa, 2003. Sustainability Analysis of Ecological and Conventional Agricultural Systems in Bangladesh. World Development, 31(10): 1721-1741.

Rola, A. C. and P. L. Pingali, 1993. Pesticides, Rice Productivity, and Farmer's Health: an economic assessment, Washington DC: World Resources Institute, International Rice Research Institute.

Sorby, K., G. Fleischer, and E. Pehu, 2003. Integrated Pest Management in Development: Review of Trends and Implementation Strategies. Agriculture and Rural Development Working Paper 5. World Bank, Washington, D.C.

SOS-Arsenic.net, 2004. Agrochemicals: Imported Pollutants in Bangladesh. Available at: http://www.sos-arsenic.net/index.html.

Spear, R., 1991. Recognized and Possible Exposure to Pesticides. Handbook of Pesticide Toxicology. Vol 1. General Principles. New York: Academic Press.

SUNS, 1998. Pesticide Overuse Takes Serious Turn in Bangladesh. Monday, Jan. 24, (Dhaka, Jan. 23 IPS/Tabibul Islam).

Tomlin, C. (ed.), 2003. The Pesticide Manual, A World Compendium (13 ${ }^{\text {th }}$ edition). British Crop Protection Council, Farnham: United Kingdom.

UBINIG, 1999. Sparrows Massacred by Pesticide in Bangladesh. Available at: http://www.ubinig.cjb.net/.

Wadud, A and B. White, 2000. Farm Household Efficiency in Bangladesh: A Comparison of Stochastic Frontier and DEA Methods. Applied Economics 32: 16651673. 
World Development Report, 2002. Building Institutions for Markets, World Bank: Washington, DC.

World Resources Institute, UNEP, UNDP, the World Bank, 1998. Environmental Change and Human Health. World Resources 1998-99.

Xuyen, K., N. C. Hoi and P. Q. Trung, 1998. Occupational Environment and Skin Diseases in Pesticide Exposed Subjects in some Tea Farms in Vietnam. Presentation given at the Third National Scientific Conference on Occupational Health, December 45, 1998. Hanoi.

Zahm, S. H., M. H. Ward and A. Blair, 1997. Pesticides and Cancer. In: Occupational Medicine: State of the Art Reviews. Vol. 12: Pesticides (Keifer, M., ed). Philadelphia: Hanley and Belfus, Inc., p.269-289. 


\section{Appendix I.}

Active Ingredients Used in the Agricultural Sector, Bangladesh.

\begin{tabular}{lrrrrrrrrr}
\hline \multicolumn{1}{c}{ Consumption (million tons) } & \multicolumn{10}{c}{ Year } \\
\hline Insecticides & $\mathbf{1 9 9 0}$ & $\mathbf{1 9 9 1}$ & $\mathbf{1 9 9 2}$ & $\mathbf{1 9 9 4}$ & $\mathbf{1 9 9 3}$ & $\mathbf{1 9 9 5}$ & $\mathbf{1 9 9 6}$ & $\mathbf{1 9 9 7}$ & $\mathbf{1 9 9 8}$ \\
Carbamate Insecticides & 170 & 182 & 202 & - & 210 & 250 & 270 & 290 & 300 \\
Chlorinated Hydrocarbons & 30 & 24 & 32 & - & 28 & 35 & 15 & 1 & - \\
Organo-Phosphates & 720 & 751 & 821 & - & 855 & 810 & 950 & 980 & 1,020 \\
Pyrethroids & 9 & 9 & 14 & - & 13 & 14 & 15 & 5 & 15 \\
Other Insecticides & 26 & 26 & 33 & - & 18 & 45 & 50 & 50 & 30 \\
Total Insecticides & $\mathbf{9 5 5}$ & $\mathbf{9 9 2}$ & $\mathbf{1 1 0 2}$ & $-\mathbf{1 1 2 4}$ & $\mathbf{1 1 5 4}$ & $\mathbf{1 3 0 0}$ & $\mathbf{1 3 2 6}$ & $\mathbf{1 3 6 5}$ \\
\hline Herbicides & & & & & & & & & \\
Bipiridils & - & - & - & - & - & 12 & 20 & 20 & 19 \\
Phenoxy Hormone Products & 9 & 10 & 10 & - & 6 & 32 & 30 & 30 & 28 \\
Other Herbicides & 26 & 25 & 23 & - & 27 & 22 & 13 & 13 & 15 \\
Total Herbicides & $\mathbf{3 5}$ & $\mathbf{3 5}$ & $\mathbf{3 3}$ & - & $\mathbf{3 3}$ & $\mathbf{6 6}$ & $\mathbf{6 3}$ & $\mathbf{6 3}$ & $\mathbf{6 2}$ \\
\hline Fungicides & & & & & & & & & \\
Benzimidazoles & - & - & 1 & - & 1 & 7 & 5 & 5 & 7 \\
Diazines, Morpholines & - & - & 1 & - & 1 & 5 & 4 & 4 & 2 \\
Dithiocarbamates & 130 & 125 & 131 & - & 120 & 132 & 155 & 170 & 320 \\
Other Fungicides & 4 & 5 & 3 & - & 6 & 6 & 5 & 5 & 23 \\
Inorganics & 142 & 130 & 175 & - & 200 & 320 & 375 & 410 & 350 \\
Triazoles, Diazoles & 276 & 260 & 1 & - & 1 & 5 & 6 & 4 & 6 \\
Fungicide \&Bacterial \&Seed Treatment & $\mathbf{2 7 6}$ & $\mathbf{2 6 0}$ & $\mathbf{3 1 2}$ & - & $\mathbf{3 2 9}$ & $\mathbf{4 7 5}$ & $\mathbf{5 5 0}$ & $\mathbf{5 9 8}$ & $\mathbf{7 0 8}$ \\
\hline Rodenticides & & & & & & & & \\
Anticoagulants & - & - & 1 & - & 1 & 2 & 2 & 1 & 2 \\
Other Rodenticides & - & - & 5 & - & - & 5 & 4 & 5 & 4 \\
Total Rodenticides & - & - & $\mathbf{6}$ & - & $\mathbf{1}$ & $\mathbf{7}$ & $\mathbf{6}$ & $\mathbf{6}$ & $\mathbf{6}$ \\
\hline Source: FAO & & & & & & & &
\end{tabular}

Source: FAO 


\section{Appendix II. Variable description and statistics}

\section{Production variables:}

Rice - measured in kilograms; combines the four seasonal varieties of rice, Aush, Boro, Irri and Aman;

Land - measured in acres;

Labor - measured in days; number of family and hired labor man-days;

Capital - measured in Taka; current worth of all farm machinery and equipment, depreciated at $10 \%$, plus equipment rental costs. Equipment rental costs are reported for each crop; equipment values are imputed in proportion to crop shares in farm production.

Irrigation and seed costs $\left(x_{\mathrm{IS}}\right)$ - measured in Taka; stated costs per crop;

Fertilizer and pesticides - measured in $\mathrm{kg}$.

\section{Eefficiency variables:}

Age - measured in years;

Education - categorical variable coded as follows:

$0=$ can't read or write/can read, but can write

$1=$ Primary $(\leq 5$ years of schooling $)$

2 = Junior high school (6-10 years of schooling)

$3=$ Secondary or Higher Secondary (11-12 years of schooling)

$4=$ Above High Secondary (more than 12 years of schooling)

Experience - Years of farming experience

Training - Dummy variable ( 1 if trained in use of pesticide applicators; 0 otherwise) 
Overall summary statistics of the sample.

\begin{tabular}{|c|c|c|c|c|c|c|c|c|}
\hline \multirow[b]{2}{*}{ Variable } & \multicolumn{4}{|c|}{ Conventional } & \multicolumn{4}{|c|}{ IPM } \\
\hline & Mean & Min. & Max. & C.V. & Mean & Min. & Max. & C.V. \\
\hline Rice production $(\mathrm{kg})$ & $3,469.23$ & 200 & 44,000 & 140 & $4,349.29$ & 400 & 27,000 & 110 \\
\hline Land (acres) & 2.40 & 0.3 & 27 & 122 & 2.73 & 0.3 & 17 & 101 \\
\hline Labor (days) & 229.45 & 11.7 & 1,487 & 140 & 171.81 & 14.1 & 1,224 & 140 \\
\hline Capital (Taka) & $3,025.13$ & 150 & 27,300 & 121 & $3,415.64$ & 200 & 39,350 & 130 \\
\hline Irrigation (Taka) & $4,038.16$ & 0 & 41,000 & 113 & $5,066.76$ & 0 & 85,000 & 160 \\
\hline Seed (Taka) & $2,468.88$ & 35 & 29,800 & 146 & $2,004.06$ & 90 & 27,800 & 152 \\
\hline Irrigation + seed (Taka) & $6,507.03$ & 350 & 53,840 & 111 & $7,070.82$ & 545 & 86,500 & 136 \\
\hline Pesticide (Taka) & $2,856.88$ & 0 & 65,189 & 206 & $1,055.27$ & 0 & 18,010 & 262 \\
\hline Fertilizer (Taka) & $4,811.25$ & 0 & 34,930 & 103 & $4,487.51$ & 120 & 27,020 & 105 \\
\hline Pesticide + fertilizer (Taka) & $7,668.13$ & 332 & 83,949 & 117 & $5,542.78$ & 120 & 40,715 & 123 \\
\hline$\overline{\text { Revenue (Taka) }}$ & $64,369.43$ & 4500 & $1,372,000$ & 158 & $49,913.09$ & 5,160 & 656,000 & 134 \\
\hline Total costs (Taka) & $26,791.03$ & 0 & 175,448 & 96 & $23,039.72$ & 1,692 & 130,319 & 97 \\
\hline Profit (Taka) & $37,578.40$ & -37562 & $1,280,800$ & 239 & $26,873.37$ & $-85,320$ & 603,235 & 215 \\
\hline Age (years) & 36.36 & 18 & 70 & 32 & 38.76 & 17 & 75 & 34 \\
\hline Education (categorical: 0-4) & 1.25 & 0 & 4 & 94 & 1.89 & 0 & 4 & 58 \\
\hline Farm size (categorical: 1-7) & 3.04 & 1 & 7 & 50 & 3.54 & 1 & 7 & 41 \\
\hline Ownership (owner=1) & 0.83 & 0 & 1 & 46 & 0.95 & 0 & 1 & 23 \\
\hline
\end{tabular}

